\title{
Intervensi Upaya Pencegahan Kebakaran Terhadap Peningkatan Pengetahuan Dan Sikap Warga Di Wilayah Pademangan Barat Jakarta Utara Tahun 2019
}

\author{
Yunia Rachmawati, Cahya Arbitera, Fajaria Nurcandra \\ Program Studi S1 Kesehatan Masyarakat, Fakultas Ilmu Kesehatan, \\ Universitas Pembangunan Nasional "Veteran” Jakarta
}

\begin{abstract}
Abstrak
Latar belakang: Pademangan Barat, Jakarta Utara adalah daerah yang dapat dikategorikan sebagai daerah yang kotor. Sebagian besar bangunan di wilayah itu adalah bangunan semi permanen dan tidak ada ruang antara satu gedung dengan gedung lainnya. Berdasarkan data di Jakarta Utara, ada 419 kasus kebakaran pada 2018 dan 53 kasus terjadi di Pademangan. Objektivitas penelitian ini adalah untuk mengetahui pengaruh intervensi pencegahan kebakaran terhadap peningkatan pengetahuan dan perilaku warga di wilayah Pademangan Barat, Jakarta Utara pada tahun 2019.

Metode: Penelitian ini adalah penelitian kuantitatif dengan rancangan penelitian pra eksperimental dengan kelompok pretest dan posttest yang tidak. termasuk membandingkan kelompok dengan jumlah sampel saya adalah 92 yang terdiri dari 46 sampel dalam kelompok ceramah dan 46 sampel dalam kelompok video yang diadakan pada bulan Mei.

Hasil: Berdasarkan hasil penelitian ini, terjadi perubahan pengetahuan (p-value 0,000) dan perilaku (p-value $0,001)$ yang terjadi pada metode intervensi dan ceramah dan ada perubahan perilaku (p-value 0,000) dan perilaku (p-value 0,029) intervensi dengan metode video kepada warga di RT 001 dan 012 di Pademangan Barat, Jakarta Utara pada 2019.

Kesimpulan: Berdasarkan hasil uji statistik, itu menunjukkan bahwa tidak ada perbedaan antara standar meningkatkan pengetahuan dan perilaku warga antara keduanya. kelompok yang diberikan metode ceramah atau video dan dapat disimpulkan bahwa tidak ada perbedaan efektivitas dalam kedua metode.
\end{abstract}

Kata kunci: Intervensi, Pengetahuan, Sikap, Pencegahan Kebakaran

\section{Interventions Fire Perventions to Increased Knowledge and Attitudes of Residents in West Pademangan Region, North Jakarta 2019}

\begin{abstract}
Background: Pademangan Barat, North Jakarta was a region that can be categorized as a vile region. Most of the building in that region was semi-permanent buildings and there was no space between one building to another. Based on the data in North Jakarta, there was 419 case of conflagration in 2018 and 53 cases of them happened in Pademangan. The objectivity of this research was to know the intervention effect of conflagration prevention to the raising knowledge and citizen's behavior in the Pademangan Barat Region, North Jakarta in 2019.

Methods: This was quantitative research along with Pre experimental study design with pretest and posttest group which was not included comparing the group with the number of me sample was 92 which consisted of 46 samples in the lecturing group and 46 samples in video group which was held in May.

Results: Based on the result of this research, there was knowledge alteration (p-value 0,000) and behavior (pvalue 0,001) which happened in intervention and lecturing method and there were behavior alteration ( $p$-value 0,000) and behavior ( $p$-value 0,029) intervention with video method to the citizens in RT 001 and 012 in Pademangan Barat, North Jakarta in 2019.

Conclusions: . Based on the result of the statistics test, it showed that there was no difference between the standards of raising knowledge and citizen's behavior between both groups who were given of either lecturing or video methods and it could be concluded that there was no difference of the effectiveness in both methods.

Keywords: Intervention, Knowledge, Attitude, Fire Prevention
\end{abstract}

\footnotetext{
Alamat Korespondensi :

Yunia Rachmawati

Fakultas Ilmu Kesehatan, Universitas Pembangunan Nasional Veteran Jakarta, Jl. Raya Limo, Depok

Email : yuniarachmawati507@gmail.com
} 


\section{PENDAHULUAN}

Bencana non alam seperti kebakaran pada saat ini masih sangat sering terjadi dan menimbulkan kerugian di berbagai faktor kehidupan seperti faktor ekonomi dan sosial Menurut Ramli kebakaran merupakan timbulnya api yang tidak terkendali yang dapat diartikan kekuatan api yang timbul tersebut diluar kemampuan dan keinginan manusia. ${ }^{1}$ Hasil pencatatan Badan Nasional Penanggulangan Bencana mengungkapkan bahwa prevalensi kejadian kebakaran di Indonesia yaitu sebesar 14,4\% selama tahun 2018 dan untuk tahun 2019 sampai dengan bulan April prevalensi kejadian kebakaran di Indonesia adalah sebesar 12,1\%., Pada tahun 2017 Dinas Pemadam Kebakaran DKI Jakarta telah mencatat telah terjadi peristiwa kebakaran sebanyak 1.471 kasus dan pada tahun 2018 tercatat sebanyak 692 kasus yang telah terjadi di wilayah DKI Jakarta. ${ }^{4}$ Jakarta Utara tercatat oleh Dinas Penanggulangan Kebakaran dan Penyelamatan Provinsi DKI Jakarta telah terjadi sebanyak 851 dan 419 kasus sepanjang tahun $2018 .{ }^{5}$

Faktor - faktor penyebab kebakaran menurut Farha dapat bersumber dari dua faktor yaitu faktor alam dan manusia. Faktor alam disebabkan karena adanya sambaran petir dan gunung meletus serta bencana alam lainnya yang menyebabkan timbulnya api penyebab kebakaran. ${ }^{6}$ Faktor manusia disebabkan karena kurangnya pengertian terhadap penanggulangan bahaya kebakaran faktor yang berasal dari manusia lain. Menurut Triyono kurangnya kehati-hatian dalam menggunkan alat atau bahan yang dapat menimbulkan api dan kurangnya kesadaran pribadi atau tidak disiplin merupakan penyebab terjadinya kebakaran yang disebabkan oleh faktor manusia, diantara kedua faktor penyebab kebakaran tersebut untuk kejadian kebakaran di wilayah permukiman warga lebih banyak disebabkan oleh faktor manusia hal ini dikarenakan oleh kepadatan penduduk di suatu wilayah yang sangat berkaitan dengan timbulnya bahaya kebakaran. ${ }^{7}$ Semakin padatnya penduduk disuatu wilayah maka akan padat pula bangunan yang didirikan disuatu wilayah tersebut. Hal ini yang akan mengakibatkan sulitnya evakusi saat kejadian kebakaran karena akses yang sangat minim. ${ }^{1}$
Dinas Penanggulangan Kebakaran dan Penyelamatan Provinsi DKI Jakarta telah menetapkan Jakarta Utara sebagai kawasan rawan terjadinya kebakaran. ${ }^{8}$ Hal ini selaras dengan hasil observasi langsung yang di dapatkan bahwa kawasan Pademangan Barat merupakan merupakan daerah padat penduduk dan dapat dikategorikan lingkungan tempat tinggal kumuh. Sebagian besar bangunan yang berada dikawasan Pademangan Barat berupa bangunan semi permanen dan jarak antar bangunan satu dengan yang lain sangat berdekatan hal ini yang akan mengakibakan cepatnya api untuk menjalar dan membesar. Berdasarkan hal tersebut peneliti tertarik untuk mengetahui dan meneliti tentang efek intervensi upaya pencegahan kebakaran terhadap peningkatan pengetahuan dan sikap warga di wilayah Pademangan Barat tahun 2019.

\section{METODE}

Penelitian ini merupakan Praeksperimen dengan racangan Pretest and Posttest Grou. Populasi dalam penelitian ini adalah warga yang tercatat tinggal di wilayah RT 001 RW 010 dan RT 012 RW 005 Pademangan Barat. Pengambilan sampel dilakukan dengan cara purposive sampling dengan jumlah sampel sebanyak 92 sampel. Variabel dependen pada penelitian ini adalah pengetahuan dan sikap warga dan variabel independen pada penelitian ini adalah intervensi upaya pencegahan kebakaran. Analisis statistik yang digunakan adalah uji Wilcoxon dan Uji Mann Whitney.

\section{HASIL}

\section{Pengetahuan}

Tabel 1. Uji non parametik (uji wilcoxon) variabel pengetahuan upaya pencegahan kebakaran

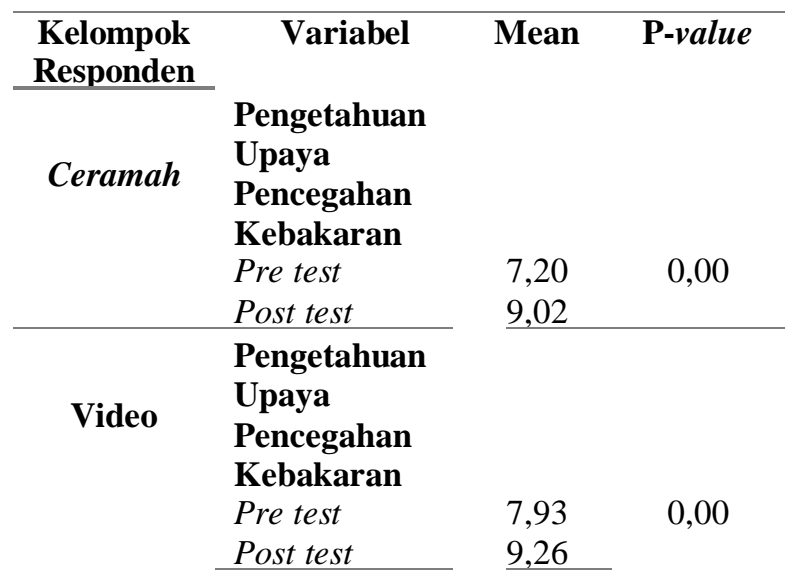


Pada hasil uji Wilcoxon pada variabel pengetahuan mengenai upaya pencegahan kebakaran dengan sampel sebanyak 46 sampel pada masing-masing kelompok telah diketahui bahwa hasil pada kelompok ceramah nilai ratarata pengetahuan sebelum diberikannya intervensi penyuluhan sebesar 7,20 dan setelah diberikannya intervensi penyuluhan sebesar 9,02 . Hasil uji statistik didapatkan nilai $p=0,00$ yang berarti ada pengaruh intervensi kesehatan terhadap peningkatan pengetahuan mengenai upaya pencegahan kebakaran pada kelompok ceramah. Hasil pada kelompok video nilai ratarata pengetahuan sebelum diberikannya

intervensi penyuluhan sebesar 7,93 dan setelah diberikannya intervensi penyuluhan sebesar 9,26 . Hasil uji statistik didapatkan nilai $p=0,00$ yang berarti ada pengaruh intervensi kesehatan terhadap peningkatan pengetahuan mengenai upaya pencegahan kebakaran pada kelompok video.

\section{Sikap}

\section{Tabel 2. Uji non parametik (uji wilcoxon) variabel sikap upaya pencegahan kebakaran}

\begin{tabular}{|c|c|c|c|}
\hline $\begin{array}{l}\text { Kelompok } \\
\text { Responden } \\
\end{array}$ & Variabel & Mean & P-value \\
\hline Ceramah & $\begin{array}{l}\text { Pengetahuan } \\
\text { Upaya } \\
\text { Pencegahan } \\
\text { Kebakaran }\end{array}$ & & \\
\hline & $\begin{array}{l}\text { Pre test } \\
\text { Post test }\end{array}$ & $\begin{array}{l}61,85 \\
66,59\end{array}$ & 0,001 \\
\hline Video & $\begin{array}{l}\text { Pengetahuan } \\
\text { Upaya } \\
\text { Pencegahan } \\
\text { Kebakaran } \\
\text { Pre test } \\
\text { Post test }\end{array}$ & $\begin{array}{l}64,02 \\
66,41 \\
\end{array}$ & 0,029 \\
\hline
\end{tabular}

Pada hasil uji Wilcoxon pada variabel sikap mengenai upaya pencegahan kebakaran dengan sampel sebanyak 46 sampel pada masing-masing kelompok telah diketahui bahwa hasil pada kelompok ceramah nilai rata-rata sikap sebelum diberikannya intervensi penyuluhan sebesar 61,85 dan setelah diberikannya intervensi penyuluhan sebesar 66,59. Hasil uji statistik didapatkan nilai $p=$ 0,001 yang berarti ada pengaruh intervensi kesehatan terhadap sikap pengetahuan mengenai upaya pencegahan kebakaran pada kelompok ceramah. Hasil pada kelompok video nilai ratarata sikap sebelum diberikannya intervensi penyuluhan sebesar 64,02 dan setelah diberikannya intervensi penyuluhan sebesar 66,41 . Hasil uji statistik didapatkan nilai $p=$ 0,029 yang berarti ada pengaruh intervensi kesehatan terhadap peningkatan sikap mengenai upaya pencegahan kebakaran pada kelompok video.

\section{Perbedaan Keefektivitasan Metode}

Tabel 3. Uji non parametik (mannwhitney) variabel pengetahuan dan sikap upaya pencegahan kebakaran

\begin{tabular}{clcc}
\hline \multicolumn{2}{c}{ Kelompok } & Mean & P-Value \\
\hline $\begin{array}{c}\text { Post-Test } \\
\text { Pengetahuan } \\
\text { upaya } \\
\text { pencegahan } \\
\text { kebakaran }\end{array}$ & Ceramah & 9,02 & \\
$\begin{array}{c}\text { Post-Test Sikap } \\
\text { upaya } \\
\text { pencegahan } \\
\text { kebakaran }\end{array}$ & Ceramah & 6,26 & 0,424 \\
& Video & 66,59 & \\
\hline
\end{tabular}

Berdasarkan hasil Tabel 3. Diatas dapat diketahui bahwa rata-rata perubahan pengetahuan pada kelompok ceramah sebesar 9,02 sedangkan untuk kelompok video sebesar 9,26 . Dari hasil uji statistik menunjukan $p$ value sebesar 0,424 sehingga dapat disimpukan bahwa tidak ada perbedaan rata-rata perubahan pengetahuan antara kelompok ceramah dan kelompok video ( $p$ value $>0,05$ ). Maka kedua metode tersebut antara ceramah dan video samasama memiliki tingkat kefektivitasan yang sama dalam meningkatkan pengetahuan dan sikap warga mengenai upaya pencegahan kebakaran. Hal ini dikarenakan pada saat pemberian intervensi penyuluhan peneliti memberikan sesi tanya jawab pada warga hal ini membuat warga pada kedua kelompok penyuluhan tersebut lebih mengerti mengenai upaya pencegahan kebakaran.

\section{PEMBAHASAN}

Pengetahuan dan Sikap Sebelum dan Sesudah Intervensi Penyuluhan pada Kelompok Ceramah

Berdasarkan hasil penelitian telah diketahui bahwa ada perbedaan pengetahuan dan sikap tentang upaya pencegahan kebakaran sebelum dan sesudah intervensi penyuluhan pada kelompok ceramah telah terjadi peningkatan rata-rata skor pengetahuan ( $p$ value $0,000)$ dan sikap ( $p$ value 0,001$)$ setelah 
intervensi penyuluhan dengan metode ceramah. Penelitian ini sesuai dengan hasil penelitian sebelumnya tentang pengaruh penyuluhan dengan metode ceramah terhadap peningkatan pengetahuan anak tentang PHBS, didapatkan hasil bahwa telah terjadi peningkatan pengetahuan pada kelompok yang diberikan penyuluhan dengan menggunakan metode ceramah, diketahui bahwa terjadi perubahan rata-rata pengetahuan responden dari sebelum diberikan penyuluhan dengan metode ceramah adalah sebesar 12,89 menjadi sebesar 21,74 sesudah diberikan penyuluhan dengan metode ceramah. ${ }^{9}$

Terjadinya peningkatan pengetahuan antara sebelum dan setelah diberikannya intervensi penyuluhan pada kelompok ceramah ini dipengaruhi oleh informasi yang telah didapatkan oleh responden setelah diberikannya intervensi penyuluhan mengenai upaya pencegahan kebakaran. Perbedaan Pengetahuan ini terjadi karena promosi kesehatan merupakan proses pendidikan untuk memperoleh sesuatu yang baru dan untuk diketahui serta dimengerti. ${ }^{10}$ Pada saat sebelum di berikannya penyuluhan rata-rata skor pengetahuan sebelum penyuluhan hanya sebesar 7,20. Namun setelah diberikannya penyuluhan mengenai upaya pencegahan kebakaran rata-rata pengetahuan warga meningkat menjadi sebesar 9,02. Untuk rata-rata sikap pada saat sebelum intervensi adalah sebesar 61,85 dan mengalami peningkatan menjadi sebesar 66,59 rata-rata sikap setelah dilakukannya penyuluhan mengenai upaya pencegahan kebakaran. Dengan demikian dapat disimpulkan bahwa melalui penyuluhan dengan metode ceramah ini dapat meningkatkan pengetahuan dan sikap responden mengenai upaya pencegahan kebakaran.

Menurut Notoatmodjo dalam proses peningkatan pengetahuan agar diperoleh hasil yang efektif diperlukan alat bantu atau media sebagai sumber informasi. Alat bantu yang digunakaan pada kelompok ceramah ini adalah slide power point yang telah di buat semenarik mungkin agar dapat menarik perhatian responden dan juga dapat mempermudah penyuluh dalam penyampaian informasi mengenai upaya pencegahan kebakaran. ${ }^{11}$ Bagi penerima pesan, gambar dan tulisan serta komposisi warna yang tepat dapat membantu dan mempermudah proses pemahaman. Sedangkan bagi pemberi pesan dapat membantu mempermudah penyampaian pesan. ${ }^{12}$
Bahasa yang digunakan penyuluh pada saat penyuluhan berlangsung juga menggunakan Bahasa sehari-hari yang mudah dimengerti oleh sasaran, seperti sistem proteksi kebakaran aktif diberikan contoh alat pemadam api. Bahasa yang digunakan pada saat penyuluhan juga dapat mempengaruhi keberhasilan penyuluhan sehingga harus digunakan Bahasa yang dapat dimengerti dan jangan menggunakan istilah asing. $^{11}$

\section{Pengetahuan dan Sikap Sebelum dan Sesudah Intervensi Penyuluhan pada Kelompok Video}

Berdasarkan hasil penelitian telah diketahui bahwa terdapat adanya perbedaan pengetahuan $(p$ value 0,000) dan sikap ( $p$ value 0,029 ) dalam upaya pencegahan kebakaran pada saat sebelum dan sesudah intervensi penyuluhan pada kelompok video. Hasil penelitian ini sesuai dengan penelitian sebelumnya tentang efektifitas media audio visual (video) terhadap peningkatan pengetahuan dimana telah didapatkan bahwa telah terjadi peningkatan pengetahuan sebesar $15,3 \%$. Nilai t hitung $-8,600$, lebih kecil dari nilai t tabel $(2,064){ }^{13}$

Adanya peningkatan pengetahuan dan sikap antara saat sebelum dan sesudah pemberian intervensi penyuluhan pada kelompok video ini dipengaruhi oleh informasi yang telah didapat oleh responden pada saat penyuluhan dengan metode pemutaran video. Pemberian informasi merupakan langkah yang tepat untuk meningkatkan pengetahuan dan sikap. ${ }^{14}$ Pada kelompok video pengetahuan sebelum penyuluhan sebesar 7,93 kemudian meningkat menjadi 9,26 setelah diberikan penyuluhan tentang upaya pencegahan kebakaran dan perubahan rata-rata sikap sebelum dilakukannya penyuluhan sebesar 64,02 kemudian meningkat menjadi 66,41 setelah diberikan penyuluhan mengenai upaya pencegahan kebakaran.

Menurut Daryanto penyuluhan dengan menggunakan metode pemutaran video akan dapat menarik perhatian para responden dan hal inilah yang penting dalam proses belajar karena dari perhatian yang timbul maka akan merangsang motivasi untuk belajar dan pesan yang akan disampaikan juga lebih efisien. ${ }^{15}$ Hasil ini mendukung penelitian sebelumnya yang menyebutkan bahwa ada perbedaan 
rata-rata peningkatan pengetahuan dalam penyuluan menggunakan metode pemutaran video. ${ }^{16}$

\section{Perbedaan Perubahan Pengetahuan dan Sikap Antara Kelompok Ceramah dan Kelompok Video}

Berdasarkan hasil penelitian ini menunjukan bahwa kedua metode yaitu ceramah dan video yang digunakan dalam memberikan intervensi penyuluhan mengenai upaya pencegahan kebakaran keduanya sama-sama dapat meningkatkan pengetahuan dan sikap warga mengenai upaya pencegahan kebakaran. Hal ini terlihat berdasarkan selisih skor pengetahuan dan sikap sesudah dan sebelum dilakukannya intervensi penyuluhan dimana keduanya mengalami peningkatan.

Berdasarkan uji statistik yang telah dilakukan untuk mengetahui perbedaan perubahan pengetahuan dan sikap pada kelompok ceramah dan video telah didapatkan bahwa nilai $p$ value pengetahuan antara kelompok ceramah dan video sebesar 0,424 sedangkan nilai $p$ value sikap antara kelompok ceramah dan video sebesar 0,899. Berdasarkan hasil tersebut dapat disimpulkan bahwa tidak adanya perbedaan rata-rata perubahan pengetahuan dan sikap antara kelompk ceramah dan video. Maka kedua metode tersebut antara ceramah dan video sama-sama memiliki tingkat kefektivitasan yang sama dalam meningkatkan pengetahuan dan sikap warga mengenai upaya pencegahan kebakaran. Hal ini dikarenakan pada saat pemberian intervensi penyuluhan peneliti memberikan sesi tanya jawab pada warga hal ini membuat warga pada kedua kelompok penyuluhan tersebut lebih mengerti mengenai upaya pencegahan kebakaran.

Dengan memberikan intervensi penyuluhan menggunakan metode ceramah akan meningkatkan pengetahuan dari responden yang bersangkutan hasil ini mendukung penelitian sebelumnya yang menyebutkan ada perbedaan rata-rata dalam peningkatan pengetahuan menggunakan metode ceramah dan penyuluhan dnegan metode ceramah lebih efektif dibandingkan dengan diskusi. ${ }^{17}$ Metode video juga dapat meningkatkan pengetahuan para responden hal ini sejalan dengan penelitian yang telah diteliti oleh Muthia, Fitriangga dan Yanti yang menyatakan bahwa Penyuluhan kesehatan dengan media audio visual efektif dalam meningkatkan pengetahuan. ${ }^{18}$

\section{KESIMPULAN}

Rata-rata pengetahuan dan sikap warga pada kelompok ceramah sebelum diberikannya kegiatan intervensi sebesar pengetahuannya
7,20 kemudian meningkat menjadi 9,20 setelah diberikan kegiatan intervensi. Untuk hasil ratarata sikap sebelum mendapatkan intervensi penyuluhan sebesar 61,83 kemudian meningkat menjadi 66,59.

Rata-rata pengetahuan dan sikap warga pada kelompok video sebelum diberikannya kegiatan intervensi pengetahuannya sebesar 7,93 kemudian meningkat menjadi 9,26 setelah diberikan kegiatan intervensi kemudian hasil rata-rata sikap sebelum mendapatkan intervensi penyuluhan sebesar 64,02 kemudian meningkat menjadi 66,41 .

Penelitian ini tidak menemukan adanya perbedaan rata-rata perubahan pengetahuan dan sikap pada kelompok ceramah dan kelompok video.

\section{DAFTAR PUSTAKA}

1. Ramli, S. (2010) Petunjuk Praktis Manajemen Kebakaran (Fire Management). Jakarta: Dian Rakyat.

2. Badan Nasional Penanggulangan Bencana (2018) Data Kejadian Bencana Kebakaran Permukiman.

3. Badan Nasional Penanggulangan Bencana Daerah (2018) Rekapitulasi Kejadian Kebakaran DKI Jakarta.

4. Dinas Pemadam Kebakaran DKI Jakarta (2017) Rekapitulasi data kejadian kebakaran DKI Jakarta

5. Dinas Penanggulangan Kebakaran dan Penyelamatan Provinsi DKI Jakarta (2017) statistik kebakaran berdasarkan penyebab.

6. Farha, A. (2010) Gambaran Sarana Proteksi Kebakaran Aktif dan Penyelamatan Jiwa. UIN Syarif Hidayatullah Jakarta.

7. Triyono, A. (2001) "teknik penaggulangan bahaya kebakaran di perusahaan". Depnaker, September, p. 34.

8. Dinas Penanggulangan Kebakaran dan Penyelamatan Provinsi DKI Jakarta (2018) Kejadian Kebakaran diJakarta Utara.

9. Lubis ZSA, Lubis NL, Syahrizal E. N/A. Pengaruh penyuluhan dengan metode ceramah dan diskusi terhadap peningkatan 
pengetahuan dan sikap anak tentang

PHBS di Sekolah Dasar Negeri

065014 Kelurahan Namogajah

Kecamatan Medan Tuntungan

tahun 2013.

10. Fatimah, A. S., Weni, K. and Th. Ninuk Sri, H. (2017) "efektivitas penyuluhan gizi menggunakan media pgs cards dibandingkan leaflet terhadap peningkatan pengetahuan pedoman gizi seimbang pada siswa sekolah dasaree.

11. Notoatmodjo, S. (2007) Promosi Kesehatan dan Ilmu Perilaku. Jakarta: Rineka cipta.

12. Dirjen PPM \& PL (2003) Panduan penggunaan media penyuluhan. Jakarta: Departemen Kesehatan RI.

13. Hamtiah S, Dwijatmiko S, Satmoko S. Efektivitas Media Audio Visual (Video) terhadap Tingkat Pengetahuan Petani Ternak Sapi Perah Tentang Kualitas Susu di Desa Indrokilo Kecamatan Ungaran Barat Kabupaten Semarang. Animal Agriculture Journal. 2012;1(2):322-30
14. Ramadhani, R. (2016) "Pengaruh Penyuluhan Gizi Tentang Makanan Beragam Bergizi Seimbang dan Aman Melalui Buku Cerita Bergambar Terhadap Peningkatan Pengetahuan dan Sikap Anak Sekolah Dasar Negeri 060895 Medan”.

15. Daryanto (2010) media pemelajaran. Yogyakarta: gava media.

16. Ameliawati, S. (2015) "Perbedaan efektivitas penyuluhan menggunakan metode demonstrasi dan pemutaran video terhadap penurunan indeks kebersihan gigi dan mulut pada siswa kelas 3 sd uchuwwatul islam kota bandung".

17. Amaliah RR, Fadhil A, Narulita S. Penerapan Metode Ceramah dan Diskusi Dalam Meningkatkan Hasil Belajar PAI di SMA Negeri 44 Jakarta. Jurnal Studi AlQur an. 2014: 10 (2), 119-131

18. Muthia F, Fitriangga A, and Yanti, SN. Perbedaan Efektifitas Penyuluhan Kesehatan menggunakan Metode Ceramah dan Media Audiovisual (Film) terhadap Pengetahuan Santri Madrasah Aliyah Pesantren Khulafaur Rasyidin tentang TB Paru Tahun 2015. Jurnal Cerebellum. 2016: 2(4); 646-656 